\title{
THE IMPLEMENTATION OF DECENTRALIZATION PROCESSES UNDER MODERN CONDITIONS OF FUNCTIONING OF THE ECONOMY OF UKRAINE
}

\author{
Ukrainian State University of Chemical Technology, Dnipro, Ukraine
}

\begin{abstract}
The relevance and importance of the practical implementation of decentralization mechanisms under the current conditions of the functioning of the Ukrainian economy with the aim of creating the basis for the growth of well-being of every citizen of the country have been emphasized. The current state of research of the theoretical and methodological foundations of the implementation of decentralization in the special and regulatory literature has been analyzed, the results of which show that attention is paid to these issues and problems. The existing types of decentralization, which are common in European countries, have been analyzed. It was found that a high level of decentralization is typical for Sweden and Denmark. It was revealed that a high level of political decentralization is peculiar to Germany, Switzerland, Belgium, Spain, very high - the Czech Republic, Portugal, Poland, Austria and Slovakia. For countries, where there is a high level of political decentralization, the level of administrative decentralization is also high, which can be of different types (deconcentrating, delegation, devolution, alienation). In most post-Soviet countries economic decentralization is common which could be achieved through the privatization of state-owned enterprises. It has been substantiated that under today's conditions for the functioning of the Ukrainian economy questions of the implementation of financial (fiscal, budget) decentralization processes, which is one of the fundamental conditions for the independence and viability of local authorities, become important. The genesis and evolution of the regulatory framework of Ukraine regarding the issues of decentralization have been analyzed. The dynamics of the share of local budgets taking into account transfers in the consolidated budget of Ukraine for 2013-2017 has been estimated. The dynamics of own resources of local budgets for 2013-2017 has been analyzed. The dynamics of the number of associations of territorial communities in Ukraine for 2015-2017 has been estimated. The expenditures of local budgets of the combined territorial communities taking into account intergovernmental transfers for 2016 in the context of the regions have been analyzed. The basic problems of decentralization inherent in the current state of transformation of the Ukrainian economy have been picked out.
\end{abstract}

Keywords: decentralization, socio-economic importance of fiscal decentralization, analysis of the implementation of fiscal decentralization in Ukraine, the main problems of fiscal decentralization.

DOI: $10.32434 / 2415-3974-2019-9-1-87-94$

\section{Introduction and problem statement}

Under current conditions the functioning of the Ukrainian economy as the most relevant and acceptable direction of the state's development should be the creation of conditions for the growth of the welfare of every citizen of the country. The achievement of such a goal is possible only in the context of the transformation of the existing system of public administration with the practical application of the experience of developed countries by increasing the influence on the vital functions of society of democratic institutions, reducing the inequality in access to public goods, improving service quality, which, ultimately, should contribute to raising the level life of the country's population. The influential and effective instrument for achieving this goal may be a mechanism and tools of fiscal decentralization in government, resulting in practical use, which

(C) Kutsynska M.V., 2019 
perform certain powers transferred to local authorities, and allowing lead to balanced state processes of public services to the needs of local communities. Ensuring the formation of effective levers of financial decentralization in the current conditions of society's life should contribute to the development of regions separately and to the increase of macroeconomic indicators in general.

Thus, the problems of transforming the financial potential of each individual region and the issue of creating conditions for the formation of financial autonomy on the basis of effective levers of fiscal decentralization are relevant in shaping the conceptual foundations for increasing the competitiveness of the region's economy and the country as a whole, as well as national security of the country.

\section{Analysis and research of publications}

At present, attention is paid to the issues of research of theoretical and methodological principles of decentralization in scientific and special literature. Thus, the processes of forming the self-development potential of Ukraine's regions in the context of transformation processes are examined [1], the problems of improving the legal and regulatory framework for the formation of local budgets under decentralization are researched [2], the role of administrative and financial decentralization as a factor for the development of subregional territorial communities is determined [3], the key trends of global experience of fiscal decentralization and ways of its implementation in Ukraine are determined [4], theoretical and methodological aspects of regulation of intergovernmental relations are analyzed [5], approaches, methods and directions of realization of financial and budgetary regulation of development of regions are offered [6], the theoretical foundations of financial decentralization are formed [7], the tendencies and problems of the formation of local budget revenues in Ukraine are estimated [8], the problems of filling local budgets in Ukraine in the context of financial decentralization are researched [9], the transformation of expenditures of local budgets in the context of fiscal decentralization are analyzed [10] and others.

\section{The purpose of the article}

The purpose of the work is to analyze the theoretical and methodological principles of the use of decentralization mechanisms in the current conditions of functioning of the country's economy in the direction of social budgeting of the regions.

\section{Presenting main material}

In various historical documents and researches of scientists the notion of «decentralization» is mentioned chronologically for the first time in relation to the Persian king Darius I (550-486 BC).

It is well known that decentralization is a management system in which some of the functions of central government are transferred to local selfgovernment bodies. In other words, decentralization involves the abolition or weakening of centralization.

Analyzing historical documents it may be noted that the first mention of the introduction of instruments of decentralization in the territory of Ukraine appears in the Constitution of the Ukrainian People's Republic of April 29, 1918. The document stated that «without violating its unified power, the UPR grants its lands, parishes and communities the right of broad self-government, while adhering to the principle of decentralization».

In general, by studying the experience of developed countries with the use of decentralization mechanisms and tools it is appropriate to note that in most European countries such means and approaches for the transfer of central government functions to local self-government bodies are rather widespread. In particular, today, a very high degree of decentralization is observed in Sweden, and the government does not interfere in the affairs of local authorities. Such a very high degree of decentralization is characteristic of Denmark.

Depending on the goals of the public administration system in relation to the application of decentralization mechanisms, its specific types are distinguished.

Thus, the goal of political decentralization is to give citizens or their elected representatives greater influence in the design and implementation of laws and policies. This primarily concerns regional representation in the national parliament, approaches to holding regional government elections and the distribution of political power on the ground, the peculiarities of building a system of constitutional law at the regional level and its relationship with the national level, etc.

Based on the results of the study of world practice of political decentralization, it is possible to state that the high level of political decentralization is characteristic of Germany, Switzerland, Belgium and Spain, rather high - for the Czech Republic, Portugal, Poland, Austria and Slovakia.

Widely used in modern conditions, the functioning of the world economy the type of decentralization is administrative, within which separate its types are distinguished, namely:

- deconcentrating, with the practical realization of which the powers of management and use of funds, as well as on the implementation of social policy are transferred from the central apparatus to the apparatus in the existing areas, but provided that direct control over the implementation of these powers is conducted from the center;

- delegation, the use of which does not involve the responsibility of semi-autonomous local self- 
government apparatus for the management and use of funds, as well as the implementation of social policy; such apparatus is not fully controlled by the central government, but ultimately accountable to them; due to the existence of such a system of delegation of administrative powers, the local government receives broad powers;

- devolution, the practical implementation of which involves the transfer of all powers in the field of management and use of funds, as well as the implementation of social policies from subnational to regional or local government (for example, the state government);

- alienation, as a type of administrative decentralization, involves the transfer of all enterprises, institutions and organizations to private ownership, with the result that there is a complete withdrawal from the state of responsibility for the management and use of finance, as well as the implementation of social policy.

From the point of view of the distribution of financial and budgetary resources of the state between the various regions, the issue of the application of financial (fiscal, budget) decentralization becomes important in the current conditions of functioning of the Ukrainian economy, which in its essence reflects the financial powers of the regional authorities and is one of the fundamental conditions for the independence and viability of local authorities. In general, an important element and component of the system of decentralization within the country through the formation of an effective self-government institution is the accumulation of a significant part of local budget revenues at the expense of local taxes and fees, which are established by such bodies independently.

According to the rules of the current legislation, fiscal decentralization involves the transfer of revenue and (or) the spending of cash and other types of financial resources to a lower level of government while retaining financial responsibility.

Sn most post-Soviet countries, economic decentralization, which may be implemented through the privatization of enterprises owned by the state, is widespread. In addition, economic decentralization can be implemented through complete deregulation and abolition of restrictions on business enterprises competing with public services, for example in the field of postal services, education, etc.

The most actual type of decentralization that should be actively implemented today in Ukraine taking into account the current state of the country's economy is certainly budget decentralization, which has a significant socioeconomic value for the development of individual industries and regions of the country, which, in the end, should lead to development and growth the country's economy as a whole.

As noted above, the main feature of a democratic state is to ensure the growth of the wellbeing of each individual citizen, and one of the main preconditions for its development is the provision of legal, organizational and financial autonomy of the system of local self-government apparatus.

Since the main instrument for social and economic policy is the budget, then budget policy should contribute to sustainable and efficient economic development. Therefore, at the current stage of management, the fiscal decentralization is the basis.

A peculiar start to budget decentralization was the introduction of amendments to the Budget and Tax Codes of Ukraine [11-12], according to which:

- the autonomy of local budgets has been expanded due to the possibility of their adoption irrespective of the adoption of the state budget;

- the local budgets set about 50 sources of income in order to increase the solvency of communities;

- the balancing system was replaced to the system of budget equalization;

- the distribution of educational and medical subventions for transfers to local self-government apparatus is established by the sectoral ministries;

- the redistribution of expenditures by state authorities and local self-government apparatus on the principle of subsidiarity has been done;

- the encouragement of territorial communities for the unification and transition to direct intergovernmental relations with the state budget was introduced.

According to the reform, the budgets of the joint territorial communities are given additional powers and appropriate financial resources, as cities of regional significance, in which there remains:

$-60 \%$ of the personal income tax;

- $100 \%$ tax on property (real estate, land, transport);

$-100 \%$ of the single tax;

- $100 \%$ excise tax on retail trade (tobacco, alcohol, petroleum products);

$-100 \%$ of the profit tax of the communal property establishments of the united territorial communities;

- $100 \%$ of payments for the provision of administrative services;

$-25 \%$ of environmental tax;

- other fees and charges, intergovernmental transfers and receipts from programs and assistance [11-12].

The budgets of the united territorial communities are financing the expenditures, which are delegated to them by the state for execution, namely (except for expenditures for the exercise of 


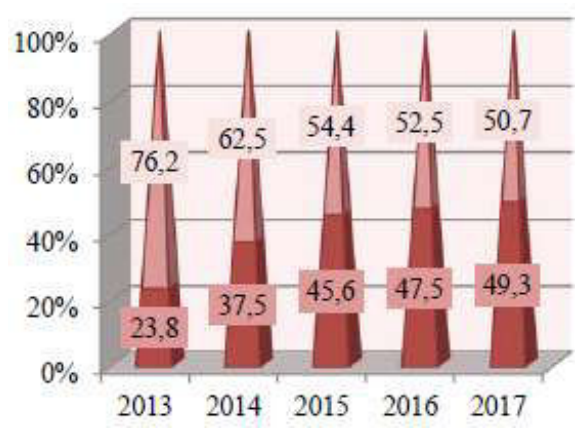

Fig. 1. Dynamics of the share of local budgets (with transfers) in the consolidated budget of Ukraine for 2013-2017, \%.

$\square-$ The share of the state budget in the consolidated budget.

$\square-$ The share of local budgets (with transfers) in the consolidated budget

self-government powers): for maintenance of institutions of budgetary sphere - education, culture, health care, sports, social protection and social security.

Up to the reform of local self-government, more than $70 \%$ of resources was concentrated in the state budget, the rest - more than $20 \%$ - in local budgets.

Beginning in 2014, there is a gradual increase in the share of local budgets in the consolidated budget (Figure 1).

The results of the study on the actual revenues of the general fund of local budgets of Ukraine during 2013-2017 showed a significant increase in the total volume of their revenues (Figure 2).

However, based on the results of the analysis of statistical data [13], it is right to note that during 2014-2017 there is a significant increase in state support for community development and infrastructure development in the regions of the country, which can be considered as another positive consequence of fiscal decentralization, and, of course, a modern step from budgets «eating» to the budgets of development.

So, based on statistics, it is possible to trace the following dynamics, namely:

- during 2014-2017 subventions for the socioeconomic development of regions increased from UAH 0.5 billion to UAH 5.0 billion;

- from 2015 to 2017 the State Fund for Regional Development increased its support for the development of communities and their infrastructure from UAH 2.9 billion in 2015 to UAH 3.5 billion in 2017;

- since 2016 the state had separate funds in the form of subventions for the infrastructure of the united territorial communities (2016 - 1,0 billion UAH, $2017-1,5$ billion UAH);

- since 2017, as a budget support article, funds are allocated in the form of subventions for the development of medicine in rural areas (UAH 4.0

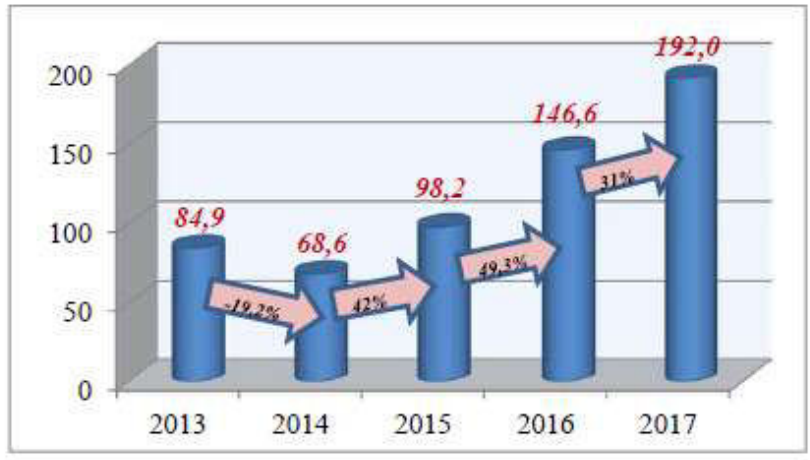

Fig. 2. Dynamics of own resources of local budgets for 20132017, UAH billions

billion), EU funds in support of sectoral regional policy (UAH 0.65 billion), etc.

An active step towards decentralization for the purpose of social budgeting of regions was the practical implementation of the process of association of territorial communities in Ukraine, which began in the middle of 2015, when 159 associations of territorial communities were formed, which brought together 795 local councils.

Figure 3 clearly confirms the positive dynamics of the number of associations of territorial communities in Ukraine; during 2015-2017, their number increased by 4.2 times (from 159 in 2015 to 665 in 2017).

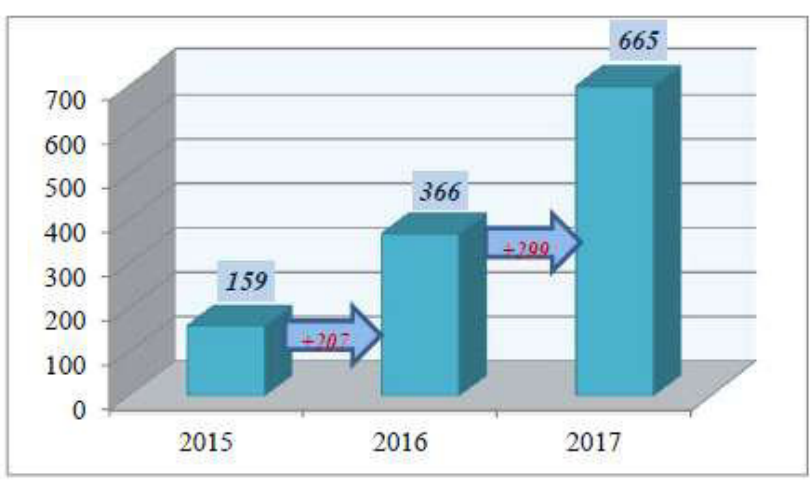

Fig. 3. The dynamics of the number of associations of territorial communities in Ukraine for 2015-2017, units

According to the rating of the five best performing regions, Dnipropetrovsk, Zhytomyr, Poltava, Zaporizhzhia and Ternopil regions make up decentralization processes.

The results of the analysis of expenditures of local budgets of the combined territorial communities taking into account intergovernmental transfers for 2016 are presented in Table.

The data in Table indicate that the process of decentralization is actively being introduced into the activity of the regions and regions of our country, which can be considered as a positive trend towards 
The implementation of decentralization processes under modern conditions of functioning of the economy

of Ukraine

\section{Analysis of expenditures of local budgets of the combined territorial communities taking into account intergovernmental transfers for 2016}

\begin{tabular}{|c|c|c|c|c|c|c|}
\hline Region name & $\begin{array}{l}\text { Expenditures, } \\
\text { UAH million }\end{array}$ & $\begin{array}{c}\text { The share of total } \\
\text { expenditures, } \%\end{array}$ & $\begin{array}{l}\text { Transfers to } \\
\text { region budget, } \\
\text { UAH million }\end{array}$ & $\begin{array}{l}\text { Share in total } \\
\text { transfers, } \%\end{array}$ & $\begin{array}{l}\text { Together, } \\
\text { million UAH }\end{array}$ & $\begin{array}{c}\text { The share of } \\
\text { total, } \%\end{array}$ \\
\hline Ternopil & 746 & 18,6 & 216 & 23,4 & 962 & 19,5 \\
\hline Khmelnitsky & 857 & 21,3 & 165 & 17,9 & 1022 & 20,7 \\
\hline Dnipropetrovsk & 448 & 11,2 & 99 & 10,7 & 547 & 11,1 \\
\hline Lviv & 173 & 4,3 & 25 & 2,7 & 198 & 4,0 \\
\hline Poltava & 273 & 6,8 & 44 & 4,8 & 317 & 6,4 \\
\hline Chernivtsi & 193,8 & 4,8 & 40 & 4,3 & 233,8 & 4,7 \\
\hline Zhytomyr & 157,3 & 3,9 & 16,5 & 1,8 & 173,8 & 3,5 \\
\hline Odesa & 220 & 5,5 & 75 & 8,1 & 295 & 6,0 \\
\hline Zaporozhye & 108,4 & 2,7 & 15,6 & 1,7 & 124 & 2,5 \\
\hline Volyn region & 54,7 & 1,4 & 25 & 2,7 & 79,7 & 1,6 \\
\hline Rivne & 91 & 2,3 & 7,2 & 0,8 & 98,2 & 2,0 \\
\hline Chernihiv & 73,1 & 1,8 & 22 & 2,4 & 95,1 & 1,9 \\
\hline Donetsk & 211,5 & 5,3 & 12 & 1,3 & 223,5 & 4,5 \\
\hline Lugansk & 23,9 & 0,6 & 52 & 5,6 & 75,9 & 1,5 \\
\hline Ivano-Frankivsk & 74,7 & 1,9 & 16,3 & 1,8 & 91 & 1,8 \\
\hline Transcarpathian & 81,1 & 2,0 & 20 & 2,2 & 101,1 & 2,0 \\
\hline Vinnitsa & 51,1 & 1,3 & 24,2 & 2,6 & 75,3 & 1,5 \\
\hline Kirovogradskaya & 54,2 & 1,3 & 26,4 & 2,9 & 80,6 & 1,6 \\
\hline Cherkassy & 54,8 & 1,4 & 9,6 & 1,0 & 64,4 & 1,3 \\
\hline Kievskaya & 27,3 & 0,7 & 6,5 & 0,7 & 33,8 & 0,7 \\
\hline Nikolaev & 12,9 & 0,3 & 1,6 & 0,2 & 14,5 & 0,4 \\
\hline Sumy & 21,4 & 0,5 & 2,5 & 0,3 & 23,9 & 0,5 \\
\hline Kherson & 9,1 & 0,1 & 0,9 & 0,1 & 10,0 & 0,3 \\
\hline Together & 4017,3 & 100,0 & 922,3 & 100,0 & 4939,6 & 100,0 \\
\hline
\end{tabular}

the search for ways of developing the regional economy and the economy within the state as a whole.

In addition to the positive phenomena that accompany the practical implementation of the mechanisms of decentralization, in particular, the budget, there is a certain range of problems.

One of the first problems that arose during the reform process, from the early stages of its proceedings, was the lack of awareness and distrust of the public to the coming changes.

Taking into account the results of the analysis of existing approaches to decentralization in the direction of social budgeting of the regions, it is possible to distinguish the following main problems of decentralization inherent in the present stage of the transformation of the Ukrainian economy, namely:

- the incompleteness of the development of perspective plans for the formation of territorial communities through, directly, and continuously making changes to those united territorial communities that have gone through the merger procedure, want to hold the first local elections and obtain additional financial resources and management powers;

- the insufficiency of legislative acts that could substantially accelerate the process of decentralization;

- the lack of comprehension of the issue of stable provision of state financial support for the voluntary association of territorial communities;

- the process of creating united territorial communities is predominantly lacking in support, and sometimes encounters a crackdown on district administrations, local councils and local elites;

- the unsettled issue of optimal distribution of powers between local governments and executive authorities in general and distribution of functions, powers between local councils of united territorial communities and rayon administrations and rayon councils of regions in particular;

- the lack of proper staffing of local governments of the united territorial communities and lack of qualifications of local government officials to perform new functions;

- the need to work out the issue of introducing mechanisms for monitoring the legality of decisions of local self-government apparatus and the quality of service provision to the population;

- the ethnization of decentralization.

In general, solving these problems will contribute to more optimal implementation of decentralization processes in all regions of the 
country, will allow to create an effective basis for a balanced social budgeting of the regions of the country, based on their current needs and directions of further development, which, in the end, should contribute to the increase of regional sectoral mezoeconomic indicators, which, in turn, have an impact on macroeconomic performance.

\section{Conclusions}

Summarizing the results of the conducted research on the current state of decentralization processes in the presence of transformational changes in the Ukrainian economy, it is worth pointing out that today there are certain problems, the presence of which is confirmed by the analyzed norms of the current Ukrainian legislation, the resolution of which requires the improvement of approaches to the construction of such a management system within the state, functioning of which will meet the modern requirements of the market space and the realities of the activities of the united territories communities and local governments.

The direction of further research in this scientific and practical domain is the assessment and analysis of the peculiarities of the ethnic composition of the regions for the implementation of decentralization processes in the context of social budgeting of the regions of Ukraine.

\section{REFERENCES}

1. Ivanova O.Iu. Formation of self-development potential of Ukrainian regions in the context of transformation processes. - Kharkiv: VD «INZhEK». - 2014.

2. Shynkariuk O., Kushlak O. (2015). Problems of improving the legal and regulatory framework for the formation of local budgets under conditions of decentralization // Svit finansiv. 2015. - Vol. 4(45). - P.76-87.

3. Buriak M.I. Administrative and financial decentralization as a factor for the development of subregional territorial communities // Visnyk DDFA ser. Economy. - 2014. - Vol. 1. - P.58-65.

4. Matsedonska, N.V., Klividenko L.M. World experience of budget decentralization and ways of its introduction in Ukraine. - [Electronic resource]. - Access mode: http:// www.easterneurope-ebm.in.ua/6-2017-ukr.

5. Tyshchenko O.M., Holiakova K.V. Theoretical and methodological analysis of aspects of regulation of inter-budgetary relations // Problemy ekonomiky. - 2012. - Vol. 1. - P.24-29.

6. Kuzmynchuk N.V. Provision of financial and budgetary regulation of regional development: approaches, methods, directions of implementation // Lviv: Liha-Pres. - 2012.

7. Drozdovska O.S. Theoretical foundations of financial decentralization // Finansy Ukrainy. - 2012. - Vol. 8. - P.1925.

8. Kulchytskyi M.I., Pazovska L.E Trends and Problems of Income Formation of Local Budgets in Ukraine // Skhidna
Yevropa: ekonomika, biznes ta upravlinnia. - 2017. - Vol. 3(08). - P.296-301.

9. Radelytskyi $Y u$. Problems of filling local budgets in Ukraine in the context of financial decentralization // Svit finansiv. - 2017. - Vol. 2(51). - P.29-41.

10. Lobodina $Z$. Transformation of local budget expenditures in the context of fiscal decentralization // Svit finansiv. - 2015. - Vol. 1. - P.69-82.

11. Budget Code of Ukraine. - [Electronic resource]. Access mode: https://zakon.rada.gov.ua/laws/show/2456-17.

12. Tax Code of Ukraine. - [Electronic resource]. - Access mode: http://zakon4.rada.gov.ua/laws/show/2755-17.

13. State Statistics Service of Ukraine. - [Electronic resource]. - Access mode: http://ukrstat.org/uk.

Received 13.04.2019

Reviewer: Doct. of Econ. Sc., Prof. Dubnitskyi V.I.

\section{ЗДІЙСНЕННЯ ПРОЦЕСІВ ДЕЦЕНТРАЛІЗАЦІЇ ЗА СУЧАСНИХ УМОВ ФУНКЦІОНУВАННЯ ЕКОНОМІКИ УКРАЇНИ}

\section{Куцинська М.В.}

Підкреслено актуальність та важливість практичноі реалізації механізмів децентралізації за сучасних умов функціонування економіки України з метою створення підгрунтя для зростання рівня добробуту кожного громадянина країни. Проаналізовано сучасний стан дослідженості теоретико-методичних засад здійснення децентралізації в спеціальній та науковій літературі, результати чого свідчать про те, що цим питанням і проблемам приділяється увага. Проаналізовано існуючі види і типи децентралізації, які є розповсюдженими у європейських країнах. Встановлено, що високий ступінь децентралізації притаманний Швеції та Данії. Виявлено, що високий рівень політичної децентралізації характерний для Німеччини, Швейиарії, Бельгії, Іспанії, дуже високий - для Чехії, Португалії, Польщі, Австрії, Словаччини. Для країн, де наявний високий рівень політичної децентралізації, високим є й рівень адміністративної децентралізації, яка буває різних типів (деконцентрація, делегування, деволюція, відчуження). У більшості пострадянських країн розповсюдженою є економічна децентралізація, що може здійснюватися шляхом приватизаціі підприємств, які належсать державі. Обгрунтовано, що за сьогоднішніх умов функціонування економіки України важливого значення набувають питання реалізації процесів фінансовоі (фіскальної, бюджетної) децентралізації, яка є однією з фундаментальних основ незалежності та життєдіяльності органів місцевої влади. Проаналізовано генезис та еволюцію нормативної бази України щодо питань децентралізації. Оцінено динаміку частки місцевих бюджетів з урахуванням трансфертів у зведеному бюджеті України за 2013-2017 рр. Проаналізовано динаміку власних ресурсів місцевих бюджетів за 2013-2017 рр. Оцінено динаміку кількості об'єднань територіальних громад в Україні за 2015-2017 рр. Проаналізовано видатки місцевих бюджетів об'єднаних територіальних громад з урахуванням міжбюджетних трансфертів за 2016 рік у розрізі областей. Виокремлено основні проблеми децентралізації, притаманні сучасному стану трансформації економіки України.

Ключові слова: децентралізація, соціально-економічне значення бюджетної децентралізації, аналіз реалізації бюджетної децентралізації в Україні, основні проблеми бюджетної децентралізації. 


\section{ОСУЩЕСТВЛЕНИЕ ПРОЦЕССОВ \\ ДЕЦЕНТРАЛИЗАЦИИ ПРИ СОВРЕМЕННЫХ УСЛОВИЯХ ФУНКЦИОНИРОВАНИЯ ЭКОНОМИКИ УКРАИНЫ}

\section{Куцинская М.В.}

Подчеркнута актуальность и важность практической реализации механизмов децентрализации при современных условиях функционирования экономики Украины с целью создания основы для роста благосостояния каждого гражданина страны. Проанализировано современное состояние исследованности теоретико-методических основ осуществления децентрализации в специальной и нормативной литературе, результаты чего свидетельствуют о том, что этим вопросам и проблемам уделяется внимание. Проанализированы существующие виды и типы децентрализации, которые являются распространенными в европейских странах. Установлено, что высокий уровень децентрализации характерен для Швеции и Дании. Выявлено, что высокий уровень политической децентрализации свойственен Германии, Швейцарии, Бельгии, Испании, очень высокий - Чехии, Португалии, Польше, Австрии, Словакии. Для стран, где присутствует высокий уровень политической децентрализации, высоким является и уровень административной децентрализации, которая бывает разных типов (деконцентрация, делегирование, деволюция, отчуждение). В большинстве постсоветских стран распространённой является экономическая децентрализация, которая может осуществляться путем приватизации предприятий, принадлежащих государству. Обосновано, что при сегодняшних условиях функционирования экономики Украины важное значение приобретают вопросы реализации процессов финансовой (фискальной, бюджетной) децентрализации, которая является одной из фундаментальных основ независимости и жизнеспособности органов местной власти. Проанализирован генезис и эволюция нормативной базы Украины относительно вопросов децентрализаиии. Оиенена динамика удельного веса местных бюджетов с учетом трансфертов в сведенном бюджете Украины за 2013-2017 г2. Проанализирована динамика собственных ресурсов местных бюджетов за 2013-2017 г2. Оценена динамика количества объединений территориальных громад в Украине за 2015-2017 г2. Проанализированы расходы местных бюджетов объединённых территориальных громад с учетом межбюджетных трансфертов за 2016 год в разрезе областей. Выделены основные проблемы децентрализации, присущие современному состоянию трансформации экономики Украины.

Ключевые слова: децентрализация, социальноэкономическое значение бюджетной децентрализации, анализ реализации бюджетной децентрализации в Украине, основные проблемы бюджетной децентрализации.

\section{THE IMPLEMENTATION OF DECENTRALIZATION PROCESSES UNDER MODERN CONDITIONS OF FUNCTIONING OF THE ECONOMY OF UKRAINE}

Kutsynska M.V.

Ukrainian State University of Chemical Technology, Dnipro, Ukraine

\section{* e-mail: ked@mail.ru}

The relevance and importance of the practical implementation of decentralization mechanisms under the current conditions of the functioning of the Ukrainian economy with the aim of creating the basis for the growth of well-being of every citizen of the country have been emphasized. The current state of research of the theoretical and methodological foundations of the implementation of decentralization in the special and regulatory literature has been analyzed, the results of which show that attention is paid to these issues and problems. The existing types of decentralization, which are common in European countries, have been analyzed. It was found that a high level of decentralization is typical for Sweden and Denmark. It was revealed that a high level of political decentralization is peculiar to Germany, Switzerland, Belgium, Spain, very high the Czech Republic, Portugal, Poland, Austria and Slovakia. For countries, where there is a high level of political decentralization, the level of administrative decentralization is also high, which can be of different types (deconcentrating, delegation, devolution, alienation). In most post-Soviet countries economic decentralization is common which could be achieved through the privatization of state-owned enterprises. It has been substantiated that under today's conditions for the functioning of the Ukrainian economy questions of the implementation of financial (fiscal, budget) decentralization processes, which is one of the fundamental conditions for the independence and viability of local authorities, become important. The genesis and evolution of the regulatory framework of Ukraine regarding the issues of decentralization have been analyzed. The dynamics of the share of local budgets taking into account transfers in the consolidated budget of Ukraine for 2013-2017 has been estimated. The dynamics of own resources of local budgets for 20132017 has been analyzed. The dynamics of the number of associations of territorial communities in Ukraine for 2015-2017 has been estimated. The expenditures of local budgets of the combined territorial communities taking into account intergovernmental transfers for 2016 in the context of the regions have been analyzed. The basic problems of decentralization inherent in the current state of transformation of the Ukrainian economy have been picked out.

Keywords: decentralization, socio-economic importance of fiscal decentralization, analysis of the implementation of fiscal decentralization in Ukraine, the main problems of fiscal decentralization. 


\section{REFERENCES:}

1. Ivanova O.Iu. (2014). Formuvannia potentsialu samorozvytku rehioniv Ukrainy $v$ konteksti transformatsiinykh protsesiv [Formation of self-development potential of Ukrainian regions in the context of transformation processes]. Kharkiv: VD «INZhEK» [in Ukrainian].

2. Shynkariuk O., Kushlak O. (2015). Problemy vdoskonalennia normatyvno-pravovoho zabezpechennia formuvannia mistsevykh biudzhetiv $\mathrm{v}$ umovakh detsentralizatsii [Problems of improving the legal and regulatory framework for the formation of local budgets under conditions of decentralization]. Svit finansiv, Vol. 4(45), 76-87 [in Ukrainian].

3. Buriak M.I. (2014). Administratyvno-finansova detsentralizatsiia yak faktor rozvytku subrehionalnykh terytorialnykh hromad [Administrative and financial decentralization as a factor for the development of subregional territorial communities]. Visnyk DDFA, Vol. 1, ser. Economy, 58-65 [in Ukrainian].

4. Matsedonska N.V., Klividenko L.M. Svitovyi dosvid biudzhetnoi detsentralizatsii ta shliakhy yoho vprovadzhennia v Ukraini [World experience of budget decentralization and ways of its introduction in Ukraine]. [Electronic resource]. - Access mode: http://www.easterneurope-ebm.in.ua/6-2017-ukr. [in Ukrainian].

5. Tyshchenko O.M., Holiakova K.V. (2012). Teoretyko-metodychnyi analiz aspektiv rehuliuvannia mizhbiudzhetnykh vidnosyn [Theoretical and methodological analysis of aspects of regulation of inter-budgetary relations]. Problemy ekonomiky, Vol. 1, 24-29 [in Ukrainian].

6. Kuzmynchuk N.V. (2012). Zabezpechennia finansovo-biudzhetnoho rehuliuvannia rozvytku rehioniv: pidkhody, meto$d y$, napriamky realizatsii [Provision of financial and budgetary regulation of regional development: approaches, methods, directions of implementation]. Lviv: Liha-Pres [in Ukrainian].
7. Drozdovska O. S. (2012). Teoretychni zasady finansovoi detsentralizatsii [Theoretical foundations of financial decentralization]. Finansy Ukrainy, Vol. 8, 19-25 [in Ukrainian].

8. Kulchytskyi M.I., Pazovska L.E. (2017). Tendentsii ta problemy formuvannia dokhodiv mistsevykh biudzhetiv $\mathrm{v}$ Ukraini [Trends and Problems of Income Formation of Local Budgets in Ukraine]. Skhidna Yevropa: ekonomika, biznes ta upravlinnia, Vol. 3(08), 296-301 [in Ukrainian].

9. Radelytskyi Yu. (2017). Problemy napovnennia mistsevykh biudzhetiv v Ukraini v konteksti finansovoi detsentralizatsii [Problems of filling local budgets in Ukraine in the context of financial decentralization]. Svit finansiv, Vol. 2(51), 29-41 [in Ukrainian].

10. Lobodina Z. (2015). Transformatsiia vydatkiv mistsevykh biudzhetiv u konteksti biudzhetnoi detsentralizatsii [Transformation of local budget expenditures in the context of fiscal decentralization]. Svit finansiv, Vol.1, 69-82 [in Ukrainian].

11. Biudzhetnyi kodeks Ukrainy zi zmin. ta dop. [Budget Code of Ukraine]. [Electronic resource]. - Access mode: https:/ /zakon.rada.gov.ua/laws/show/2456-17 [in Ukrainian].

12. Podatkovyi kodeks Ukrainy zi zmin. ta dop. [Tax Code of Ukraine]. [Electronic resource]. - Access mode: http:// zakon4.rada.gov.ua/laws/show/2755-17 [in Ukrainian].

13. Derzhavna sluzhba statystyky Ukrainy [State Statistics Service of Ukraine]. [Electronic resource]. - Access mode: http://ukrstat.org/uk [in Ukrainian]. 